\title{
Establishment of the mayfly Cloeon dipterum as a new model system to investigate insect evolution
}

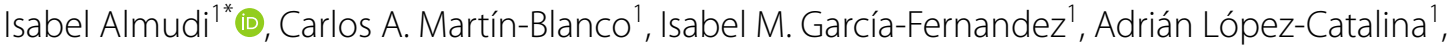 \\ Kristofer Davie ${ }^{2,3}$, Stein Aerts ${ }^{2,3}$ and Fernando Casares ${ }^{1 *}$
}

\begin{abstract}
The great capability of insects to adapt to new environments promoted their extraordinary diversification, resulting in the group of Metazoa with the largest number of species distributed worldwide. To understand this enormous diversity, it is essential to investigate lineages that would allow the reconstruction of the early events in the evolution of insects. However, research on insect ecology, physiology, development and evolution has mostly focused on few well-established model species. The key phylogenetic position of mayflies within Paleoptera as the sister group of the rest of winged insects and life history traits of mayflies make them an essential order to understand insect evolution. Here, we describe the establishment of a continuous culture system of the mayfly Cloeon dipterum and a series of experimental protocols and omics resources that allow the study of its development and its great regenerative capability. Thus, the establishment of Cloeon as an experimental platform paves the way to understand genomic and morphogenetic events that occurred at the origin of winged insects.
\end{abstract}

Keywords: Evolutionary and developmental biology, Insect evolution, Embryogenesis, Paleoptera, Mayflies, Ephemeroptera, Cloeon dipterum, Regeneration

\section{Introduction}

Insects are the most diverse group of Metazoa, harbouring the largest number of animal species [1]. Insects comprise more than thirty extant orders distributed worldwide-they are found in all sorts of habitats including marine environments [2,3]. Despite the fact that other animals populated the land before insects, like chelicerates and myriapods [4-6], the appearance of winged insects meant a complete biological revolution with profound effects on the history of life on earth. The colonisation of the air allowed insects unprecedented dispersal capacities and novel ecological interactions-such as their role as pollinator agents that drove the further coevolution of insects and angiosperms.

\footnotetext{
*Correspondence: isabelalmudi@gmail.com; fcasfer@upo.es

${ }^{1}$ GEM-DMC2 Unit, The CABD (CSIC-UPO-JA), Ctra. de Utrera km 1,

41013 Seville, Spain

Full list of author information is available at the end of the article
}

Although the impact that the appearance of insects had in the shaping and evolution of, not only their own group, but also other phyla and even kingdoms, our knowledge of insects comes mainly from work on a handful of wellestablished model species. Among them, Drosophila melanogaster, which is one of the best-studied model organisms, is broadly used in multiple fields of research, including the evo-devo field [7-9]. Probably, the second most used insect in evolutionary and developmental studies is Tribolium castaneum (Coleoptera), followed by some butterfly and moth (Lepidoptera) species. In addition to these established models, other dipterans with important impact on human health (as vectors transmitting diseases: Anopheles, Glossina, Aedes) and economy (e.g. agricultural pests: Ceratitis capitata, D. suzukii) have been studied in more detail. Unfortunately, these insect orders are all part of the holometabola group of hexapoda, which appeared relatively recently within the insect phylogeny ([10] and references therein). Some efforts have been made in order to fill the gap in 
hemimetabola, with the introduction of species such as Oncopeltus fasciatus [11], Blattella germanica [12] and Gerris buenoi or Rhagovelia antilleana [13, 14].

This dearth of laboratory models is even more acute in the case of early branching insect groups that correspond to the first representatives of the crucial biological and ecological transitions mentioned above. For instance, key adaptations to terrestrial life such as the development of the extra-embryonic tissues amnion and serosa [15-19], the establishment of early embryo segmentation mechanisms and the transition from short-to-long-germ band mode of embryogenesis [20-24], the basal organisation of the head $[25,26]$, or the origin of wings and the capacity to fly (an issue that is currently hotly debated [27-35]). Overall, these examples point to important questions that are still open, ultimately revealing the need for establishing new model systems, in particular around the nodes of the tree where these key novelties/ adaptations originated.

The advent of next-generation sequencing (NGS) techniques and new genome-editing technologies allow the re-examination of long-standing questions in evo-devo using comparative approaches. However, one of the challenges is getting access to the biological material, especially at the desired developmental stage for a particular study. Thus, there is a great interest in increasing the number of emergent model organisms that due to their key phylogenetic position or their specific traits would permit evo-devo studies in the precise clade of interest. Here, to contribute in this direction, we developed an Ephemeroptera laboratory model, Cloeon dipterum.

Ephemeroptera (mayflies) is an order of winged hemimetabola insects that live in freshwater ecosystems. The Ephemeroptera order has over 3000 species distributed in 40 different families approximately [36, 37]. Mayflies belong to an ancient group of insects that were present already in the late Carboniferous or early Permian period [1]. Mayflies have a life cycle that consists of two welldefined phases. The aquatic phase that comprises embryogenesis and nymphal stages and the terrestrial phase, which consists on a sexually immature subimago and a sexually active imago (Fig. 1). Their aquatic phase makes mayflies ideal as bioindicators of the quality of freshwater ecosystems [38-40], while their terrestrial phase contributes to population dispersal; thus, mayflies have been used to investigate biogeographical events, such as dispersion and colonisation of new communities [41-43]. The duration of embryogenesis is variable, ranging from days to months, depending on the species and environmental factors, as the temperature [44]. Although the life cycle of some species, like Baetis vernus, Ephemerella ignita and Ephoron shigae, includes a programmed egg-dormancy phase or diapause [45-48], this is not the case for $C$. dipterum. Once the nymphs eclode from the eggs, they undergo a series of moults to finally moult into a terrestrial subimago that leaves the water. This sexually immature individual has to moult once more to become the sexually mature imago. This two-step moulting into the sexually mature individual is a striking singularity of mayflies $[49,50]$. The mating occurs in flying swarms formed by hundreds of individuals several metres above the ground/water surface level [51-53].

In most phylogenetic analyses, Ephemeroptera is grouped together with Odonata (damselflies and dragonflies) as the sister group of Neoptera, the rest of winged insects ([54] and references therein). Therefore, extant mayflies are a key order to test the hypotheses postulated for the wing origin in pterygote insects. Their position in the phylogenetic tree also makes them an essential group to investigate segmentation, head specification and other morphogenetic processes occurring in the embryo, beyond the classical insect models already used to address these problems (Drosophila, Tribolium, Oncopeltus). Moreover, their particular life cycle with an aquatic and a terrestrial period makes mayflies a relevant organism to examine different adaptations to the land, such as the evolution of the extra-embryonic layers and other metabolic and physiologic traits derived from this complex life cycle, such as the hormonal control, ecdysis and metabolic rates.

By having established C. dipterum in the laboratory, we have now unlimited access to all embryonic and postembryonic stages through the year, permitting the study of fundamental processes that originated for the first time in Ephemeroptera or that are specific to the extant members of this order. Moreover, the development of a series of genomic and transcriptomic resources will facilitate comparative analyses at the genome, transcriptome and epigenomic levels that can clarify the role of certain genes and regulatory networks in the origin of those novelties. Finally, the high regenerative capabilities of C. dipterum [55-57], together with its short life cycle (which lasts from 40 to 60 days on average), make this species a significant and very useful system to investigate the regeneration of non-embryonic tissues in insects.

\section{C. dipterum continuous culture in the laboratory}

Cloeon dipterum, from the Baetidae family, is one of the few ovoviviparous ephemeropteran species: the female keeps the fertilised eggs inside the abdomen and only when they are ready to hatch, after 10-20 days, the female sets down onto the surface of a water stream or pond and lays the eggs that sink to the bottom ready to eclode. Just few seconds after the eggs are laid, the nymphs hatch [58]. 

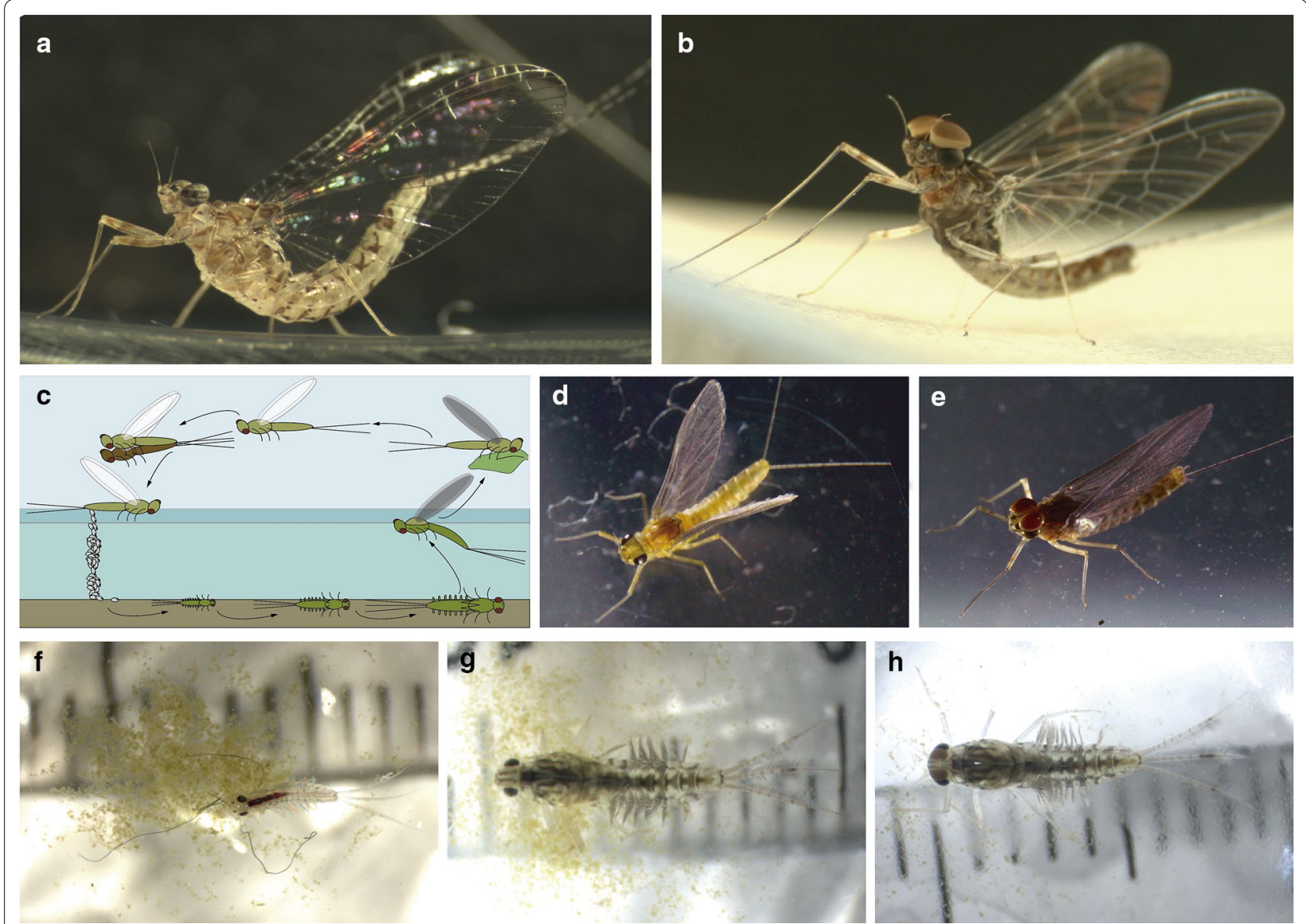

Fig. 1 C. dipterum life cycle. a C. dipterum adult female, b C. dipterum adult male. c Cartoon depicting C. dipterum life cycle. Female lays the eggs in a water stream where they hatch as juvenile nymphs. After several moults nymphs emerge from the water to the land as immature subimagos. Then, they moult again to become sexually mature individuals that fly forming swarms to mate. $\mathbf{d}$ Female subimago. e Male subimago. $\mathbf{f}$ Early-mid nymph. $\mathbf{g}$ Late female nymph. $\mathbf{h}$ Late male nymph

Individual lines were established and maintained in the laboratory for multiple generations starting from single gravid females captured in Dos Hermanas (Sevilla, Spain) and Alfacar (Granada, Spain). In the laboratory, gravid females are kept in a petri dish with a wet filter paper to avoid their desiccation. After 13 days, the female is first placed on the surface of unchlorinated water in a beaker to let it lay the eggs, but the duration of embryogenesis is a bit variable, between 13 and 17 days. If the embryos are ready to hatch, females immediately spawn. However, in case she does not spawn within the first minute on the water, the female has to be brought back to the petri dish to avoid the laying of underdeveloped eggs. It is therefore advisable to try to induce the spawning during several days until reaching the appropriate moment when the embryos are fully developed. The number of eggs a female can lay depends mainly on its nutritional condition. In general, bigger females produce larger clutches. In the laboratory, the females tend to lay between one hundred and three hundred eggs per clutch. Shortly after delivering the eggs, the females die.

The hatchlings take only a few seconds to hatch (Fig. 2b-e, Additional files 1 and 2) as swimming nymphs. They instantly start feeding on algae that are placed at the bottom of a $1000 \mathrm{ml}$ beaker with approximate $700 \mathrm{ml}$ of water. In the moment of hatching, the nymphs do not have external gills. It is only two moults later, approximately $72 \mathrm{~h}$ after hatching that seven pairs of gills are visible in the first seven abdominal segments. The nymphs are kept in the unchlorinated water in the beaker during the whole juvenile period. A portion of the water is replaced once a week, though the frequency can be increased if the culture becomes cloudy due to an excess of mayfly faeces or the overgrowth of algae. A bubbling tube connected to an air pump is introduced in the water to oxygenate it (Fig. 2f). The nymphs feed regularly on Chara, filamentous algae, pulverised vegetarian 

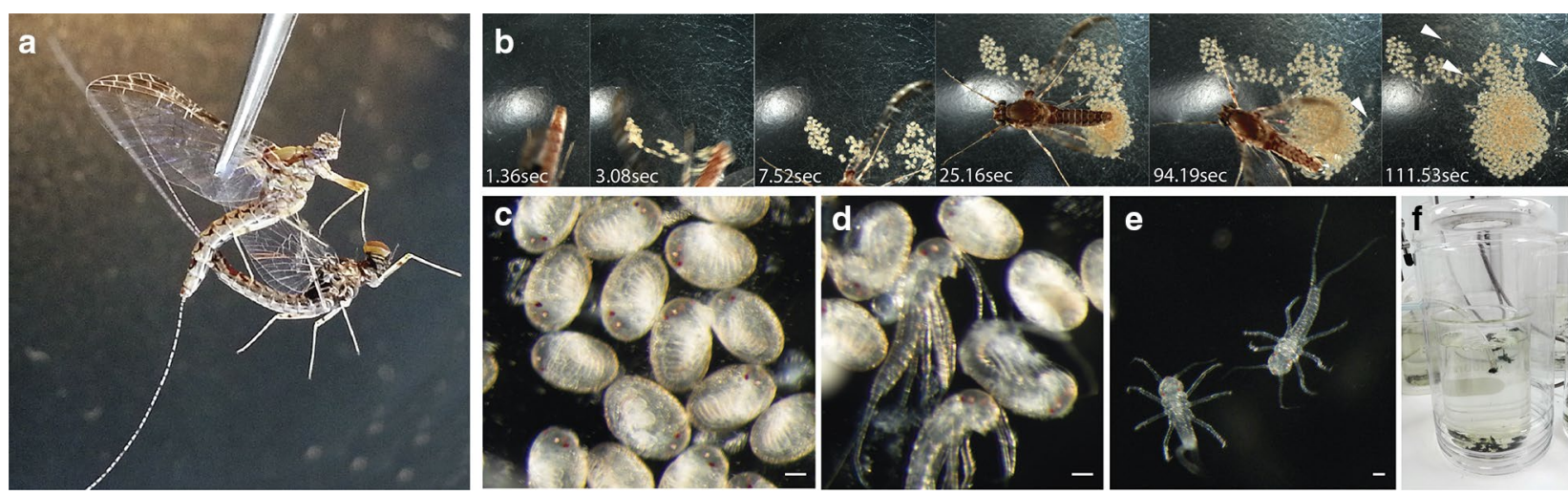

Fig. 2 C. dipterum culture in the laboratory. a Couple of adults mating through forced copula. b Temporal sequence of a gravid female laying fertilised eggs that after 94 s hatch as swimming nymphs (white arrowheads). c, d Fertilised eggs and nymphs hatching. e Freshly hatched nymphs. f Culture system in the laboratory. Nymphs are in the beaker with bubbling water and algae. The beaker is placed inside a plastic bottle to keep the subimagos once they emerge from the water. Scale bars: $50 \mu \mathrm{m}$

fish flakes or small pieces of carrot that are added to the water.

The beakers are placed inside $10 \mathrm{l}$ plastic bottles (Fig. 2f), so when subimagos emerge from the last nymphal stage and leave the water, they remain inside the bottle and can be easily recovered. To avoid water condensation that could damage the newly emerged subimagos while they stay inside the plastic bottles, the plastic upper side is replaced by a small net. The subimagos are carefully collected and kept for $24 \mathrm{~h}$ in a tube with some wet paper to maintain the humidity and promote the last moult to imago, which happens some hours after the previous moult. To close the cycle in the laboratory, it is necessary to perform forced copulas [59], since mayflies mate during flight in large swarms [51-53]. To perform the mating, both male and female are grasped very carefully by the wings with forceps. The female is placed with the ventral side upwards and the most posterior region of the male is brought close to the female seventh abdominal segment. Males, then, clasp the abdomen of the female using their genital forceps or stylus, allowing the contact of the two external genitalia to engage the copula (Fig. 2a). Copulas have a variable duration: they can last from few seconds to several minutes. During this time, males bend themselves to favour the fertilisation of the eggs. After the copula, the male is discarded and the female is kept in a petri dish with a small piece of humidified filter paper. The culture is maintained in a 21-23 degrees Celsius room and a 12:12 light/dark illumination cycle.

\section{C. dipterum embryogenesis}

The establishment of the continuous culture of $C$. dipterum in the laboratory allows the study of the complete embryogenesis of these mayflies by obtaining the embryos directly from the abdomen of gravid females. Once the embryos are collected, it is possible to use antibodies and other markers to visualise the morphology of the embryo and morphogenetic processes occurring at specific developmental stages (Fig. 3).

Cloeon dipterum embryogenesis takes between 13 and 17 days, depending on the temperature. The morphogenesis in this species is similar to the previously described embryogenesis of other mayflies [60, 61]. Briefly, after egg cleavage the blastoderm is formed. Within the blastoderm, two populations of cells are soon distinguishable, the most posterior ones, with smaller nuclei that will form the germ disc and the larger and more anterior cells that will become the serosa (Fig. 3a, b). Thereafter, the germ disc starts elongating and the future cephalic region and future caudal segment addition zone become apparent. During the following highly proliferative stages, as showed by an increased density of PH3-positive mitotic cells (Fig. $3 c^{\prime}-e^{\prime}$ ), the embryo elongates within the egg, adopting a S-shape (Fig. 3c). As the embryo elongates, its most posterior region, which will correspond to abdominal segments, folds several times. After this phase, the embryo reaches its final length and its segmentation starts. Segmentation happens from anterior to posterior, with cephalic and thoracic appendages being the first to become visible (Fig. 3d). Afterwards, the embryo undergoes a series of final developmental events in which its final form is completed, including the appearance of the caudal filament, the two posterior cerci, the three ocelli and the compound eyes (Fig. 3e, f).

Beyond general morphology, access to all developmental stages also allows the study of the development of specific tissues and organs. We have tested protocols 


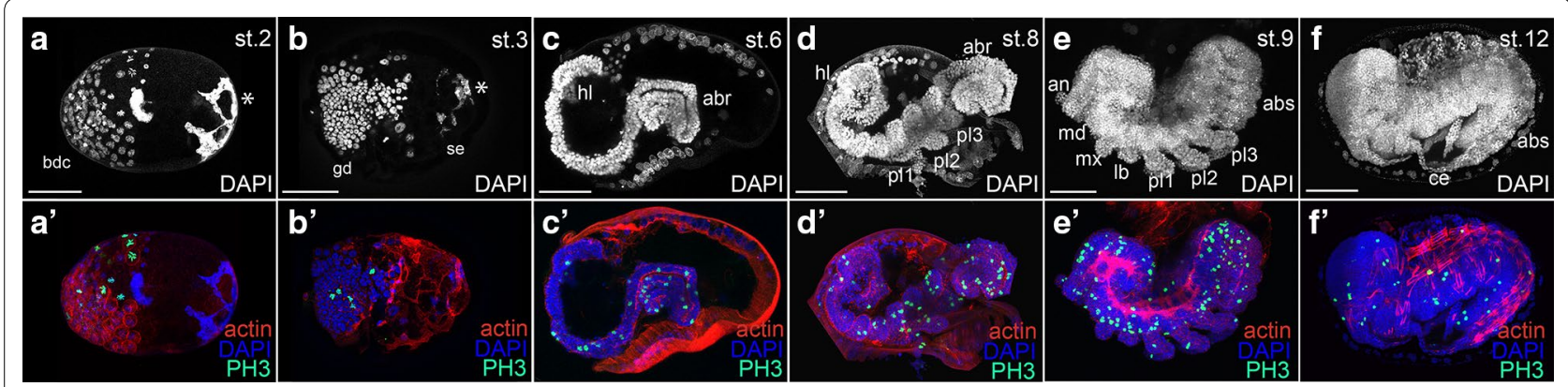

Fig. 3 Representative phases of C. dipterum embryogenesis. Upper panels show embryo morphology detectable through DAPI staining (white). Lower panels show DAPI (nuclei, blue), Actin (cell contour cRed) and mitosis (anti-PH3, green). a-a' Blastoderm formation (stage 2: st. 2) bcd: blastoderm cells are replicating, shown by PH3 staining $\left(\mathbf{a}^{\prime}\right)$, in green. The asterisk highlights a DAPI-rich region located opposite to the embryo with unknown function. b-b' Germ disc (gd) formation (st. 3). The asterisk highlights a DAPI-rich region located opposite the embryo which we have not identified. It disappears during subsequent stages. $\mathbf{c}-\mathbf{c}^{\prime}$ S-shaped embryo (st. 6). The germ band elongates through active cell proliferation, shown by PH3 staining (abr: abdominal region; hl: head lobe). $\mathbf{d}-\mathbf{d}^{\prime}$ Segmentation of the embryo (st. 8) starts from the cephalic (hl) and thoracic regions, which segments are already visible, towards the abdominal regions (abr). e-e' Proctodaeum formation (st. 9). Segmentation progresses, appendages enlarge and get segmented (an: antenna, md: mandible, mx: maxilla, lb: labium, pl: pro-leg). f-f' The abdominal regions are already segmented (abs: abdominal segments). Cercei (ce) are already visible. Dorsal closure proceeds. Scale bars: $50 \mu \mathrm{m}$
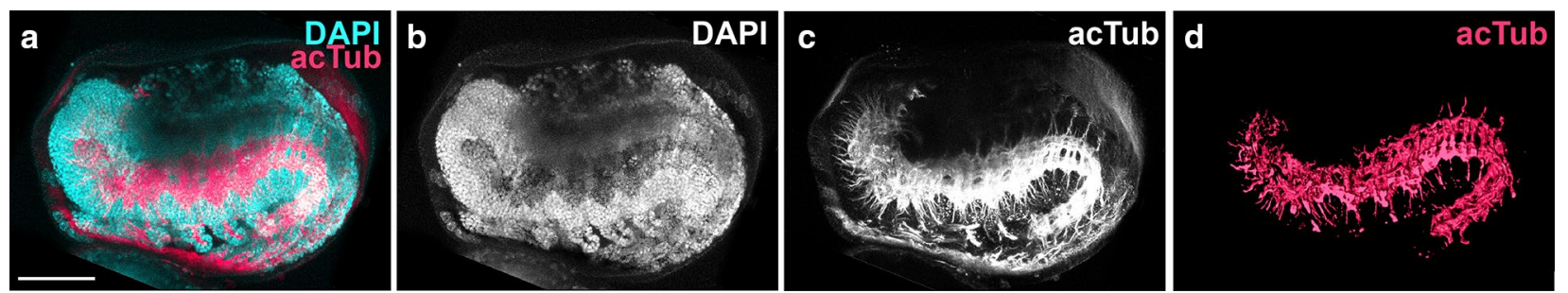

Fig. 4 C. dipterum embryonic nervous system. a-c Embryo (DAPI staining reveals embryo morphology, b exhibiting the ventral nervous cord (staining using anti-acetylated alpha Tubulin antibody, $\mathbf{c}$ ). $\mathbf{d}$ Surface reconstruction of the ventral nervous cord and its projections towards the appendages. Scale bars: $50 \mu \mathrm{m}$

for immunofluorescence and in situ hybridisation (ISH) using non-radioactively labelled RNA probes to detect gene expression. We illustrate these protocols with the anti-acetylated Tubulin (acTub) antibody to mark axonal projection of the nervous system (Fig. 4) and with RNA probes against orthodenticle (otd) or engrailed (en) that define specific embryonic regions, such as the optic region and the segmental borders, respectively (Fig. 5c, d).

\section{The transcriptome of $C$. dipterum}

Until now, there were no appropriate genomic tools available to investigate $C$. dipterum at the genetic level. Only a genomic survey sequencing for molecular markers to study $C$. dipterum population structure using 454 technology at low coverage has been reported [41, 62]. Therefore, to carry out the first characterisation of $C$. dipterum gene content, we sequenced the transcriptome of a male nymph. The assembly of the paired-end reads, using Trinity RNA-Seq de novo assembly software [63] resulted in 117233 transcripts. From these 117233 transcripts, we obtained 95053 peptide sequences using transDecoder [64] to get the longest translated ORFs. Running BLASTp, we got a list of 15799 sequences from UniRef90 database which showed homology to other sequences $(e$-value $<10 e-6)$. These hits showed a majority of results, more than $80 \%$ (13059 best hits), within the hexapoda (insects and Collembola). The second most frequent groups of hits fell within Arthropoda (Chelicerata and Myriapoda, $4.24 \%$ ) and Crustacea (4.15\%) categories, which demonstrated the good quality of the assembly (Fig. 5b). Less frequent categories present in our best hit results corresponded, on the one hand, to bacteria and virus which probably derive from the mayfly microbiota, and on the other hand, Plantae and Red algae, which most likely belong to the gut content of the specimen at the moment of the RNA extraction, as $C$. dipterum feeds on algae and plants.

Although the transcriptome generated was obtained from a single male nymph, and it thus represents only the genes that are expressed at that particular developmental stage, it can nevertheless serve as a very 


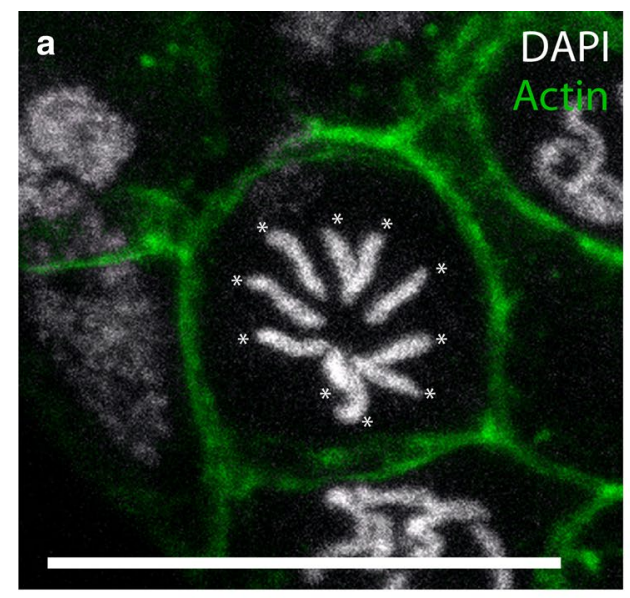

C

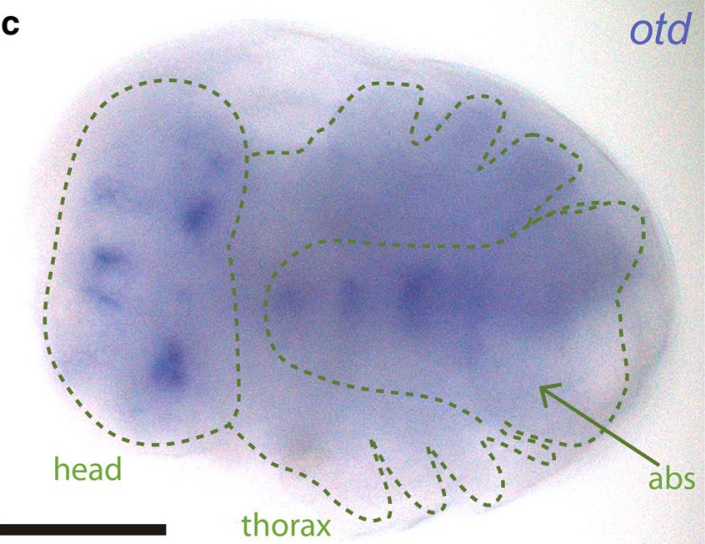

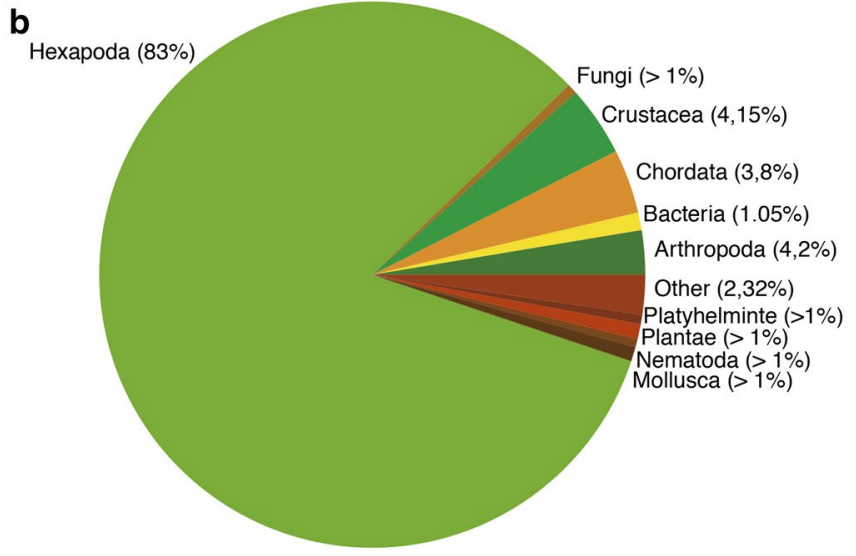

d

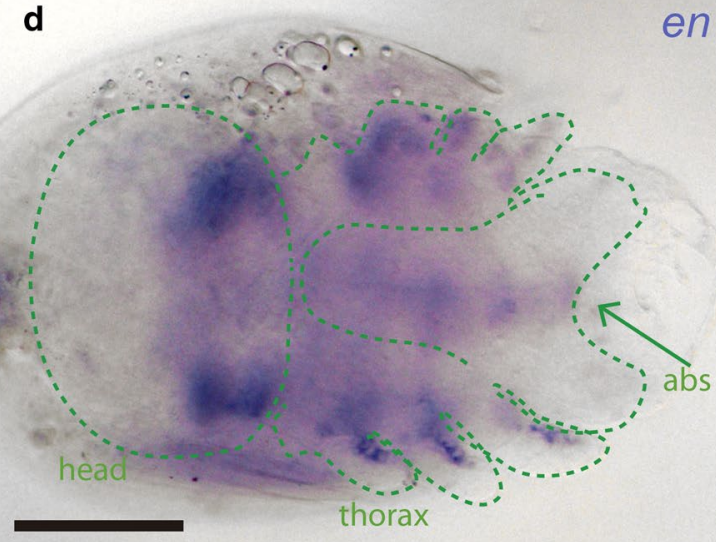

Fig. 5 Genomics and transcriptomic tools. a The genome of C. dipterum is structured in a karyotype of $2 n=10$ [95, 96]. Somatic embryonic cell showing condensed DNA in chromosomes (each of them highlighted with an asterisk). DNA stained with DAPI (white) and cell membrane visible through Phalloidin-Rhodamine staining (green). Scale bar: $20 \mu \mathrm{m}$. b Pie chart representing top BLASTp results of unigenes against UniRef90 protein database. c otd expression pattern in the mayfly embryo. d en expression domain in C. dipterum embryo

useful resource to identify homologous transcripts and to design probes to perform subsequent expression pattern analyses of genes of interest expressed during nymphal stages and other stages, as in the case of orthodenticle (otd) and engrailed (en) (real time PCRs, in situ hybridisation, Fig. 5c, d).

This transcriptome assembly is a first step in order to have resources that can be used to tackle questions in the evolution of first winged insects at a genomic/ transcriptomic level. Nevertheless, more tools are needed, so the high-quality genome sequencing project that is currently in progress will provide an invaluable resource and a platform for subsequent analyses (ATAC-Seq, Chip-Seq, etc.) to investigate long-standing questions related to the origin of pterygotes and other important traits that contributed to the diversification of insects.

\section{The regenerative potential of $C$. dipterum}

The capacity to regenerate lost or damaged organs, body parts (or even whole organisms) is widespread throughout the animal kingdom [65-67]. Several phyla, such as Cnidaria, Platyhelminthes, Annelids, Arthropods or Vertebrates, have this ability. However, different species or even phyla have very different regenerative capabilities. For instance, Platyhelminthes (flatworms) use totipotent cells called neoblasts, to regenerate a complete organism from a few hundred cells [68-74], while other organisms, such as the crustacean Parhyale, rely on the dedifferentiation of cell populations to re-grow amputated limbs $[66,75,76]$. Despite the diversity of species that are able to regenerate and the varying modes, mechanisms and degrees of their regeneration capabilities, only a small number of organisms have been used to investigate how regeneration occurs. This is particular evident for insects, 

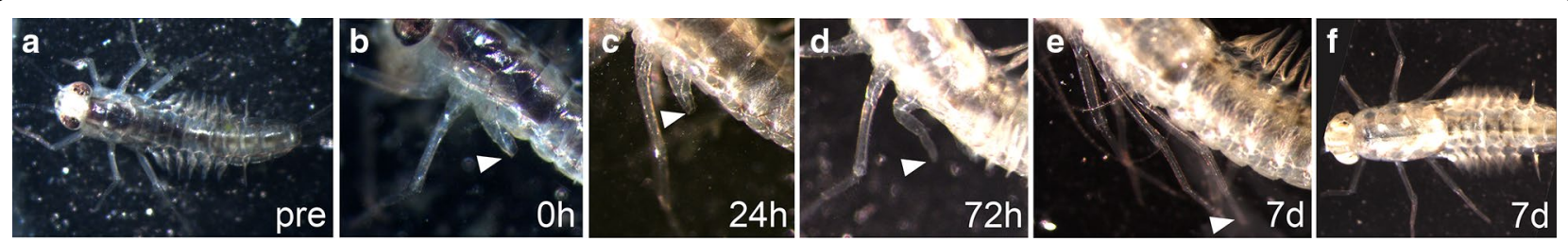

Fig. 6 Leg regeneration of a C. dipterum nymph. a Mayfly nymph before amputation of the third leg. b Nymphal leg (white arrowhead) immediately after amputation. c $24 \mathrm{~h}$ after amputation the wound is healed (arrowhead). $\mathbf{d} 72 \mathrm{~h}$ after amputation, the tissue is already partially regenerated. e, $\mathbf{f}$ After 7 days, the amputated leg has recovered its initial size and shape with all the segments perfectly formed

where only a handful of species have been used as models for regeneration studies [77], namely Drosophila melanogaster, which only regenerates undifferentiated primordia - the imaginal discs - and the gut [78-89], and two hemimetabolous insects, the cockroach Blattella germanica [90, 91] and the cricket Gryllus bimaculatus, which can take from 1 month to 18 weeks to regenerate an amputated limb [91-93].

Dewitz, already in 1890, described that mayfly nymphs were able to regenerate their gills completely after amputation [56]. Since then, several researchers [55, 57] confirmed these observations. Indeed, we observed that $C$. dipterum is able to regenerate gills, antennae, cerci and legs completely in a very short period of time, ranging from 6 to 9 days (Fig. 6). For instance, after amputation of the third pair of legs, C. dipterum takes less than $24 \mathrm{~h}$ to heal the wound and only $72 \mathrm{~h}$ to exhibit a clear regrowth of the appendage, completing the entire process in a period of no more than 7 days (Fig. 6). Thus, C. dipterum has extraordinarily rapid regenerative capabilities that could give this species a privileged status because of its fast regeneration of postembryonic, fully functional organs.

\section{Conclusions}

Although Ephemeropterans have been the focus of biogeography, taxonomy and ecology studies, until now they have been very rarely used as a laboratory model to address developmental and evolutionary questions $[35,94]$, despite the fact they are fundamental to understand insect evolution at multiple time scales. Here, we present $C$. dipterum as an emergent model for evo-devo studies. There are several traits in this species that make it especially useful to answer long-standing questions in evolutionary biology. First, the setting up of a continuous culture system in the laboratory facilitates the access to all the developmental stages, and because of the ovoviviparism of $C$. dipterum, it allows having high numbers of synchronised embryos. The continuous culture also permits to obtain large amounts of material that can be used in genomics and transcriptomics assays. Second, the use of forced copulas ensures a complete control on the mating, so it is feasible to have inbred lines to reduce genetic heterozygosity which is necessary for genetic experiments or when applying functional genomics techniques. Moreover, the relatively short life cycle of C. dipterum permits the investigation of embryonic and postembryonic processes in a brief period of time and making experimental designs feasible. Although RNA interference techniques are not established in the mayfly yet, its aquatic life phase allows us to perform drug treatments, for example, to interfere with signalling pathways, by just adding the molecules to the water. However, these functional experiments are limited by the number of drugs available to alter specific gene networks, thus, efforts must be made to set up interference RNA and CRISPR/Cas9 methods to downregulate genes or edit the genome in C. dipterum.

Moreover, the generation of omic resources, through the sequencing of $C$. dipterum genome and different tissue- and stage-specific RNA-seq datasets, and the development of protocols to investigate changes in regulatory regions of the genome, such as ATAC-seq and ChIPseq techniques, will provide a great resource to investigate evolutionary and developmental questions at the genomic level.

Beyond the technical and methodological advantages that $C$. dipterum confers, the key phylogenetic position, ecology, physiology and plasticity of mayflies make them an essential order to investigate very diverse topics, from genomic and morphogenetic events that occurred at the origin of winged insects, the origin of metamorphosis and hormone control of ecdysis, to the regenerative potential in insects.

\section{Additional files}

Additional file 1. Female laying a clutch of embryos after being placed on the water surface.

Additional file 2. Nymphs hatching from the eggs few seconds after being laid. 


\section{Authors' contributions}

IA and FC conceived and designed the study. IA and CM-B established and maintained C. dipterum culture. IA and CM-B performed embryogenesis characterisation. IA, IMG-F and AL-C performed in situ hybridisation experiments. IA, KD and SA generated and analysed the transcriptome data. CM-B and IA performed regeneration assays. IA prepared the figures and wrote the manuscript with the help of FC and inputs from all authors. All authors read and approved the final manuscript.

\section{Author details}

1 GEM-DMC2 Unit, The CABD (CSIC-UPO-JA), Ctra. de Utrera km 1 , 41013 Seville, Spain. ${ }^{2}$ Laboratory of Computational Biology, VIB Center for Brain \& Disease Research, Herestraat 49, 3000 Louvain, Belgium. ${ }^{3}$ Department of Human Genetics, KU Leuven, Oude Markt 13, 3000 Louvain, Belgium.

\section{Acknowledgements}

We thank David Funk, Pablo Jáimez and Julio Miguel Luzón for helping and advising on the collection and establishment of the $C$. dipterum continuous culture in the laboratory and Zeynep Kalender, Maxime Dewaegeneer and Stephane Rombauts for helping in the initial analyses of the transcriptome. We also thank the CABD Fish facility, the CABD Genomics platform and members of the Martinez-Morales lab for providing filamentous algae to feed the mayflies, the CABD ALMI platform for confocal microscopy support and Ignacio Maeso for critically reading the manuscript. This project has been funded by the European Union's Horizon 2020 research and innovation programme under the Marie Sklodowska-Curie Grant Agreement 657732 to IA, Grant BFU2015-66040-P to FC and institutional Grant MDM-2016-0687 (MINECO, Spain).

\section{Competing interests}

The authors declare that they have no competing interests.

\section{Availability of data and materials}

RNA-seq data are publicly available in NCBI under accessions BioProject ID: PRJNA515246.

\section{Publisher's Note}

Springer Nature remains neutral with regard to jurisdictional claims in published maps and institutional affiliations.

Received: 17 January 2019 Accepted: 21 March 2019

Published online: 02 April 2019

\section{References}

1. Misof B, Liu S, Meusemann K, Peters RS, Donath A, Mayer C, et al. Phylog enomics resolves the timing and pattern of insect evolution. Science. 2014;346(6210):763-7.

2. Collins NM, Thomas JA. The conservation of insects and their habitats. London: Academic Press; 1991.

3. Andersen NM. The evolution of marine insects: phylogenetic, ecological and geographical aspects of species diversity in marine water striders. Ecography. 1999;22(1):98-111.

4. Lozano-Fernandez J, Carton R, Tanner AR, Puttick MN, Blaxter M, Vinther J, et al. A molecular palaeobiological exploration of arthropod terrestrialization. Philos Trans R Soc B Biol Sci. 2016;371:20150133.

5. Rota-Stabelli O, Daley Allison C, Pisani D. Molecular timetrees reveal a Cambrian colonization of land and a new scenario for ecdysozoan evolution. Curr Biol. 2013;23(5):392-8.

6. Little C. The colonisation of land: origins and adaptations of terrestrial animals. Cambridge: Cambridge University Press; 1983. p. 241-72.

7. Hilbrant M, Almudi I, Leite DJ, Kuncheria L, Posnien N, Nunes MD, et al. Sexual dimorphism and natural variation within and among species in the Drosophila retinal mosaic. BMC Evol Biol. 2014;14:240.

8. Kittelmann S, Buffry AD, Franke FA, Almudi I, Yoth M, Sabaris G, et al. Gene regulatory network architecture in different developmental contexts influences the genetic basis of morphological evolution. PLoS Genet. 2018;14(5):e1007375.
9. Smith SJ, Rebeiz M, Davidson L. From pattern to process: studies at the interface of gene regulatory networks, morphogenesis, and evolution. Curr Opin Genet Dev. 2018;51:103-10.

10. Schmidt-Ott U, Lynch JA. Emerging developmental genetic model systems in holometabolous insects. Curr Opin Genet Dev. 2016;39:116-28.

11. Chipman AD. Oncopeltus fasciatus as an evo-devo research organism. Genesis. 2017;55(5):e23020.

12. Korb J, Belles X. Juvenile hormone and hemimetabolan eusociality: a comparison of cockroaches with termites. Curr Opin Insect Sci. 2017;22:109-16

13. Santos $M E$, Le Bouquin A, Crumière AJJ, Khila A. Taxon-restricted genes at the origin of a novel trait allowing access to a new environment. Science. 2017;358(6361):386-90.

14. Toubiana W, Khila A. The benefits of expanding studies of trait exaggeration to hemimetabolous insects and beyond morphology. Curr Opin Genet Dev. 2016;39:14-20.

15. Schmidt-Ott U, Kwan CW. Morphogenetic functions of extraembryonic membranes in insects. Curr Opin Insect Sci. 2016;13:86-92.

16. Jacobs CGC, Rezende GL, Lamers GEM, van der Zee M. The extraembryonic serosa protects the insect egg against desiccation. Proc R Soc B. 2013;280:20131082.

17. van der Zee M, Berns N, Roth S. Distinct functions of the Tribolium zerknu-l/t genes in serosa specification and dorsal closure. Curr Biol. 2005:15(7):624-36.

18. Jacobs CGC, Spaink HP, van der Zee M. The extraembryonic serosa is a frontier epithelium providing the insect egg with a full-range innate immune response. eLife. 2014;3:e04111.

19. Hilbrant M, Horn T, Koelzer S, Panfilio KA. The beetle amnion and serosa functionally interact as apposed epithelia. eLife. 2016;5:e13834.

20. Auman T, Chipman AD. Growth zone segmentation in the milkweed bug Oncopeltus fasciatus sheds light on the evolution of insect segmentation. BMC Evol Biol. 2018;18(1):178.

21. Zhu X, Rudolf H, Healey L, François P, Brown SJ, Klingler M, et al. Speed regulation of genetic cascades allows for evolvability in the body plan specification of insects. Proc Natl Acad Sci. 2017;114(41):E8646-55.

22. Liu PZ, Kaufman TC. Short and long germ segmentation: unanswered questions in the evolution of a developmental mode. Evolut Dev. 2005;7(6):629-46.

23. Stahi R, Chipman AD. Blastoderm segmentation in Oncopeltus fasciatus and the evolution of insect segmentation mechanisms. Proc R Soc B. 2016;283:20161745.

24. Peel A. The evolution of arthropod segmentation mechanisms. BioEssays. 2004;26(10):1108-16.

25. Magri MS, Domínguez-Cejudo MA, Casares F. Wnt controls the mediallateral subdivision of the Drosophila head. Biol Lett. 2018;14:20180258.

26. Posnien N, Schinko JB, Kittelmann S, Bucher G. Genetics, development and composition of the insect head - a beetle's view. Arthropod Struct Dev. 2010;39(6):399-410.

27. Hamilton KGA. The insect wing. Part 1. Origin and development of wings from notal lobes. J Kansas Entomol Soc. 1971;44:421-33.

28. Rasnitsyn AP. A modified paranotal theory of insect wing origin. J Morphol. 1981;168(3):331-8.

29. Ohde T, Yaginuma T, Niimi T. Insect morphological diversification through the modification of wing serial homologs. Science. 2013;340(6131):495-8.

30. Averof M, Cohen SM. Evolutionary origin of insect wings from ancestral gills. Nature. 1997;385(6617):627-30.

31. Clark-Hachtel CM, Tomoyasu Y. Exploring the origin of insect wings from an evo-devo perspective. Curr Opin Insect Sci. 2016;13:77-85.

32. Kukalova-Peck J. Origin and evolution of insect wings and their relation to metamorphosis, as documented by the fossil record. J Morphol. 1978;156(1):53-125.

33. Kukalová-Peck J. Origin of the insect wing and wing articulation from the arthropodan leg. Can J Zool. 1983;61(7):1618-69.

34. Linz DM, Tomoyasu Y. Dual evolutionary origin of insect wings supported by an investigation of the abdominal wing serial homologs in Tribolium. Proc Natl Acad Sci USA. 2018;115(4):E658-67.

35. Niwa N, Akimoto-Kato A, Niimi T, Tojo K, Machida R, Hayashi S. Evolutionary origin of the insect wing via integration of two developmental modules. Evolut Dev. 2010;12(2):168-76. 
36. Barber-James HM, Gattolliat J-L, Sartori M, Hubbard MD. Global diversity of mayflies (Ephemeroptera, Insecta) in freshwater. Hydrobiologia. 2008;595(1):339-50.

37. Sartori M, Brittain JE. Chapter 34-Order ephemeroptera. In: Thorp JH, Rogers DC, editors. Thorp and Covich's freshwater invertebrates. 4th ed. Boston: Academic Press; 2015. p. 873-91.

38. Chou H, Pathmasiri W, Deese-spruill J, Sumner SJ, Jima DD, Funk DH, et al. The good, the bad, and the lethal: gene expression and metabolomics reveal physiological mechanisms underlying chronic thermal effects in Mayfly larvae (Neocloeon triangulifer). Front Ecol Evolut. 2018;6(27):1-11.

39. Peschke K, Geburzi J, Köhler H-R, Wurm K, Triebskorn R. Invertebrates as indicators for chemical stress in sewage-influenced stream systems: toxic and endocrine effects in gammarids and reactions at the community level in two tributaries of Lake Constance, Schussen and Argen. Ecotoxicol Environ Saf. 2014;106:115-25.

40. Scarduelli L, Giacchini R, Parenti P, Migliorati S, Di Brisco AM, Vighi M. Natural variability of biochemical biomarkers in the macro-zoobenthos: dependence on life stage and environmental factors. Environ Toxicol Chem. 2017;36(11):3158-67.

41. Rutschmann S, Detering H, Simon S, Funk DH, Gattolliat J-L, Hughes SJ, et al. Colonization and diversification of aquatic insects on three Macaronesian archipelagos using 59 nuclear loci derived from a draft genome. Mol Phylogenet Evol. 2017;107:27-38.

42. Vuataz L, Rutschmann S, Monaghan MT, Sartori M. Molecular phylogeny and timing of diversification in Alpine Rhithrogena (Ephemeroptera: Heptageniidae). BMC Evol Biol. 2016;16(1):194.

43. Gueuning M, Suchan T, Rutschmann S, Gattolliat J-L, Jamsari J, Kamil $\mathrm{Al}$, et al. Elevation in tropical sky islands as the common driver in structuring genes and communities of freshwater organisms. Sci Rep. 2017;7(1):16089.

44. Humpesch UH. Effect of fluctuating temperature on the duration of embryonic development in two Ecdyonurus spp. and Rhithrogena cf. hybrida (Ephemeroptera) from Austrian streams. Oecologia. 1982;55(3):285-8.

45. Watanabe NC, Takao S. Effect of a low temperature period on the egg hatching of the Japanese burrowing mayfly, Ephoron shigae. In: Alba-Tercedor J, Sánchez-Ortega A, editors. Overview and strategies of Ephemeroptera and Plecoptera. Florida: Sandhill Crane Press; 1991. pp 439-445.

46. Bohle HW. Die Temperaturabhangigkeit der Embryogenese und der embryonalen Diapause von Ephemerella ignita (Poda) (Insecta, Ephemeroptera). Oecologia. 1972;10:253-68.

47. Bohle HW. Untersuchungen über die Embryonalentwicklung und die embryonale Diapause bei Baetis vernus CURTIS und Baetis rhodani (Pictet) (Baetidae, Ephemeroptera). Zool Jb Anat Bd. 1969;86, S.:493-575.

48. Clifford HF. Life cycles of mayflies (Ephemeroptera), with special reference to voltinism. Quaest Entomol. 1982;18(1-4):15-90.

49. Edmunds JGF, McCafferty WP. The mayfly subimago. Ann Rev Entomol. 1988:33:509-29.

50. Maiorana VC. Why do adult insects not moult? Biol J Lin Soc. 1979;11(3):253-8

51. Harker JE. Swarm behaviour and mate competition in mayflies (Ephemeroptera). J Zool. 1992;228(4):571-87.

52. Allan JD, Flecker AS. The mating biology of a mass-swarming mayfly. Anim Behav. 1989;37:361-71.

53. Peckarsky BL, McIntosh AR, Caudill CC, Dahl J. Swarming and mating behavior of a mayfly Baetis bicaudatus suggest stabilizing selection for male body size. Behav Ecol Sociobiol. 2002;51 (6):530-7.

54. Simon S, Blanke A, Meusemann K. Reanalyzing the Palaeoptera problem-the origin of insect flight remains obscure. Arthropod Struct Dev. 2018;47(4):328-38.

55. Cuénot L. L'adaptation: les Impr. réunies; 1925.

56. Dewitz H. Einige Beobachtungen betreffend das geschlossene Tracheensystem bei Insektenlarven. Zool Anz. 1890;13(345):525-31.

57. Wingfield CA. The function of the gills of mayfly nymphs from different habitats. J Exp Biol. 1939;16(3):363-73.

58. Berner L. Ovoviviparous mayflies in Florida. Fla Entomol. 1941;24(2):32-4.
59. Huff BL Jr, McCafferty WP. Parthenogenesis and experimental reproductive biology in four species of the mayfly genus stenonema. Wasmann $J$ Biol. 1974;32(2):247-54.

60. Bohle HW. The effect of temperature on embryogenesis and diapause of Ephemerella ignita (Poda). Oecologia. 1972;10(3):253-68.

61. Tojo K, Machida R. Early embryonic development of the mayfly Ephemera japonica McLachlan (Insecta: Ephemeroptera, Ephemeridae). J Morphol. 1998;238(3):327-35.

62. Rutschmann S, Detering H, Simon S, Fredslund J, Monaghan MT. discomark: nuclear marker discovery from orthologous sequences using draft genome data. Mol Ecol Resour. 2017;17(2):257-66.

63. Grabherr MG, Haas BJ, Yassour M, Levin JZ, Thompson DA, Amit I, et al. Full-length transcriptome assembly from RNA-Seq data without a reference genome. Nat Biotechnol. 2011;29(7):644-52.

64. Haas BJ, Papanicolaou A, Yassour M, Grabherr M, Blood PD, Bowden J, et al. De novo transcript sequence reconstruction from RNA-seq using the Trinity platform for reference generation and analysis. Nat Protoc. 2013;8(8):1494-512

65. Bely AE, Nyberg KG. Evolution of animal regeneration: re-emergence of a field. Trends Ecol Evol. 2010;25(3):161-70.

66. Grillo M, Konstantinides N, Averof M. Old questions, new models: unraveling complex organ regeneration with new experimental approaches. Curr Opin Genet Dev. 2016;40:23-31.

67. Morgan TH. Regeneration. London: The Macmillan Company; 1901.

68. Atabay KD, LoCascio SA, de Hoog T, Reddien PW. Self-organization and progenitor targeting generate stable patterns in planarian regeneration. Science. 2018;360(6387):404-9.

69. Cebria F, Adell T, Salo E. Rebuilding a planarian: from early signaling to final shape. Int J Dev Biol. 2018;62(6-7-8):537-50.

70. Egger B, Gschwentner R, Hess MW, Nimeth KT, Adamski Z, Willems M, et al. The caudal regeneration blastema is an accumulation of rapidly proliferating stem cells in the flatworm Macrostomum lignano. BMC Dev Biol. 2009;9:41.

71. Egger B, Ladurner P, Nimeth K, Gschwentner R, Rieger R. The regeneration capacity of the flatworm Macrostomum lignano-on repeated regeneration, rejuvenation, and the minimal size needed for regeneration. Dev Genes Evol. 2006;216(10):565-77.

72. Plass M, Solana J, Wolf AJ, Ayoub S, Misios A, Glažar P, Obermayer P, Theis FJ, Kocks C, Rajewsky N. Cell type atlas and lineage tree of a whole complex animal by single-cell transcriptomics. Science. 2018;360(6391):eaaq1723. https://doi.org/10.1126/science.aaq1723.

73. Nimeth KT, Egger B, Rieger R, Salvenmoser W, Peter R, Gschwentner R. Regeneration in Macrostomum lignano (Platyhelminthes): cellular dynamics in the neoblast stem cell system. Cell Tissue Res. 2007;327(3):637-46.

74. Reddien PW. The cellular and molecular basis for planarian regeneration. Cell. 2018;175(2):327-45.

75. Konstantinides N, Averof M. A common cellular basis for muscle regeneration in arthropods and vertebrates. Science. 2014;343(6172):788-91.

76. Alwes F, Enjolras C, Averof M. Live imaging reveals the progenitors and cell dynamics of limb regeneration. eLife. 2016;5:e19766.

77. Egger B, Gschwentner R, Rieger R. Free-living flatworms under the knife: past and present. Dev Genes Evol. 2007;217(2):89-104.

78. Hariharan IK, Serras F. Imaginal disc regeneration takes flight. Curr Opin Cell Biol. 2017;48:10-6.

79. Repiso A, Bergantiños C, Corominas M, Serras F. Tissue repair and regeneration in Drosophila imaginal discs. Dev Growth Differ. 2011;53(2):177-85.

80. Vizcaya-Molina E, Klein CC, Serras F, Mishra RK, Guigo R, Corominas M. Damage-responsive elements in Drosophila regeneration. Genome Res. 2018;28:1852-66.

81. Ahmed-de-Prado S, Baonza A. Drosophila as a model system to study cell signaling in organ regeneration. Biomed Res Int. 2018;2018:7359267.

82. Guo Z, Lucchetta E, Rafel N, Ohlstein B. Maintenance of the adult Drosophila intestine: all roads lead to homeostasis. Curr Opin Genet Dev. 2016:40:81-6

83. Ahmed-de-Prado S, Diaz-Garcia S, Baonza A. JNK and JAK/STAT signalling are required for inducing loss of cell fate specification during imaginal wing discs regeneration in Drosophila melanogaster. Dev Biol. 2018:441(1):31-41. 
84. Bergantinos C, Corominas M, Serras F. Cell death-induced regeneration in wing imaginal discs requires JNK signalling. Development. 2010;137(7):1169-79.

85. Blanco E, Ruiz-Romero M, Beltran S, Bosch M, Punset A, Serras F, et al. Gene expression following induction of regeneration in Drosophila wing imaginal discs. Expression profile of regenerating wing discs. BMC Dev Biol. 2010;10:94

86. Bosch M, Bishop SA, Baguna J, Couso JP. Leg regeneration in Drosophila abridges the normal developmental program. Int J Dev Biol. 2010;54(8-9):1241-50

87. Bosch M, Serras F, Martin-Blanco E, Baguna J. JNK signaling pathway required for wound healing in regenerating Drosophila wing imaginal discs. Dev Biol. 2005:280(1):73-86.

88. Harris RE, Setiawan L, Saul J, Hariharan IK. Localized epigenetic silencing of a damage-activated WNT enhancer limits regeneration in mature Drosophila imaginal discs. Elife. 2016;5:1-28.

89. Santabarbara-Ruiz P, Lopez-Santillan M, Martinez-Rodriguez I, BinaguiCasas A, Perez L, Milan M, et al. ROS-induced JNK and p38 signaling is required for unpaired cytokine activation during Drosophila regeneration. PLoS Genet. 2015:11(10):e1005595.
90. French V. Leg regeneration in the cockroach, Blatella germanica. II Regeneration from a non-congruent tibial graft/host junction. J Embryol Exp Morphol. 1976;35(2):267-301.

91. Nakamura T, Mito T, Bando T, Ohuchi H, Noji S. Molecular and cellular basis of regeneration and tissue repair. Cell Mol Life Sci. 2007;65(1):64

92. Bando T, Mito T, Hamada Y, Ishimaru Y, Noji S, Ohuchi H. Molecular mechanisms of limb regeneration: insights from regenerating legs of the cricket Gryllus bimaculatus. Int J Dev Biol. 2018;62(6-7-8):559-69.

93. Das S. Morphological, molecular, and hormonal basis of limb regeneration across Pancrustacea. Integr Comp Biol. 2015;55(5):869-77.

94. O'Donnell BC, Jockusch EL. The expression of wingless and Engrailed in developing embryos of the mayfly Ephoron leukon (Ephemeroptera: Polymitarcyidae). Dev Genes Evol. 2010;220(1):11-24.

95. Kiauta B, Mol AWM. Behaviour of the spermatocyte chromosomes of the mayfly, Cloeon dipterum (Linnaeus, 1761) s.1. (Ephemeroptera: Baetidae), with a note on the cytology of the order. Genen Phaenen. 1977;19(2/3):31-9.

96. Wolf E. Zur Karyologie der Eireifung und Furchung bei Cloeon dipterum L. (Bengtsson)(Ephemerida, Baetidae). Biol Zbl. 1960;79:153-98.
Ready to submit your research? Choose BMC and benefit from:

- fast, convenient online submission

- thorough peer review by experienced researchers in your field

- rapid publication on acceptance

- support for research data, including large and complex data types

- gold Open Access which fosters wider collaboration and increased citations

- maximum visibility for your research: over 100M website views per year

At BMC, research is always in progress.

Learn more biomedcentral.com/submissions 